IJTC

Ilomata International Journal of Tax \& Accounting

P-ISSN: 2714-9838; E-ISSN: 2714-9846

Vol. 1 No. 4 October 2020 pp.256-263

https://www.ilomata.org/index.php/ijtc

\title{
Corporate Social Responsibility And Financial Ratio on Market Value Added
}

\author{
Diyah Santi Hariyani ${ }^{1}$, L. H. Almira Salatnaya ${ }^{2}$, D. Dwi Mardani ${ }^{3}$ \\ ${ }^{13}$ Universitas PGRI Madiun University \\ ${ }^{2}$ Muhammadiyah high school of economics in Tuban \\ Correspondent: diyah.santi@unipma.ac.id
}

Submitted : September 25, $2020 \quad$ Revised : October 10, $2020 \quad$ Published : October 31, 2020

\begin{abstract}
The purpose of this study is to empirically examine the Effect of Corporate Social Responsibility (CSR) and Financial Ratio on Market Value Added (MVA), both simultaneously and partially. This research was conducted using a sample of 33 companies winning 2016 CSR and Top CSR 2017 Appreciation by determining their samples (purposive sampling) because there were certain considerations over a period of 2 years (2015-2016). The results of this study indicate that simultaneously the effect of CSR and Financial Ratio together does not significantly influence Market Value Added (MVA). And partially ISO9001, ISO14001, ISO26000, OHSAS18001, Current Ratio (CR), Debt to Equity Ratio (DER), Price Earnings Ratio (PER), Total Asset Turnover and Return on Sales do not significantly influence MVA. While partially only ESOP has a significant effect on MVA.
\end{abstract}

Keywords: Corporate Social Responsibility, Financial Ratio, Market Value Added

\section{INTRODUCTION}

The performance of the company is not only focused on the disclosure of the company's financial information, but the company is expected to disclose information relating to nonfinancial matters such as; social and environmental problems. This measure of non-financial performance is a driving indicator to measure progress in financial performance because this measure can be used in the current economic conditions in Indonesia. One of the non-financial elements expressed is social responsibility or Corporate Social Responsibility (CSR) (Ioannou \& Serafeim, 2010).

The increasing level of competition faced by companies in the present era raises various awards given to companies to appreciate the achievement of company performance. Several awards are given certainly have international standards or commonly referred to as the International Organization for Standardization (ISO) or other certificates relating to CSR practices. The International Organization for Standardization (ISO) has a variety of forms, one of which will be a measure in this study including ISO 9001, ISO 14001, ISO26000, besides that there is another certificate, OHSAS18001, Employee Stock Option Program (ESOP).

In ISO 9001, it addresses international standards on the issue of quality standards of a company. ISO 14001 is an international standard in which there are environmental issues. At present, Corporate Social Responsibility (CSR) is characterized by international standard initiatives, namely ISO26000. ISO26000 states that Corporate Social Responsibility (CSR) is a form of corporate social care that is currently an important aspect to improve company performance in addition to quality and environmental issues (Rachman et al., 2011: 37). 
According to (Kurnia, Tandiontong, \& Maranatha, 2015), OHSAS18001 is the standard of Corporate Social Responsibility (CSR) which contains safety and health standards, while the Employee Stock Option Program (ESOP) is to support the alignment of objectives between the company and its employees so that companies can create stock incentive programs for the employee.

Measurement of company performance is also measured using financial ratios. The ratio is designed to show the relationship between financial statement estimates. According to (Zhang, 2016), financial statement analysis aims to determine the ability of companies to generate profits, prospects and the level of risk of investment in shares of a company. With this financial ratio analysis, companies can find out how much the percentage (\%) the company is experiencing growth. Besides, companies can find out how much they're strength in providing or generating funds with financial ratio analysis.

Market Value Added (MVA) is a measurement of the performance of other companies. Market Value Added is a performance measurement concept that is still related to Economic Value Added (EVA) which is more focused on the total value of a company at a certain point such as the value-added balance sheet (GS \& Rahmansyah, 2017). Market Value Added (MVA) is the size of the company to determine future performance where the main component in this measure is the price of the stock market, and the Economic Value Added (EVA) is the size of the company that measures past performance (Song \& Peng, 2015). In measuring using MVA this is an important factor to get the value of the company. Giving awards to the company is expected to be a push for the company to be more advanced because the company's financial condition is considered not to have problems.

Market Value Added (MVA) can be described as the performance of a company. Good company performance will create a good corporate image. The relationship between Corporate Social Responsibility (CSR) and Market Value Added (MVA) according to (Hsu-Chien, 2010) has a close relationship, that is, when the company establishes social and environmental responsibility properly the company's image improves.

Financial ratios and company performance also have a close relationship. For investors, the use of ratios can be adjusted to the analysis that will be carried out because the ratio has its uses(Putri, 2014). The ratio becomes the basis for analyzing the condition of a company. The healthy condition of the company will certainly add a good corporate image to the community.

Previous research conducted by (Novita, 2013) in manufacturing and mining companies in the period 2007-2011 explained that social responsibility showed a positive relationship with Market Value Added (MVA). (Kurnia et al., 2015) explained that ESOP, ISO 9001, ISO 14001, OHSAS 18001, Current Ratio (CR), Debt-to-Equity Ratio (DER), Total Asset Turnover (TAT), Return on Sales (ROS), Price Earnings Ratio (PER) have a significant effect on Market Value Added (MVA) while based on (Abdurachman \& Gustyana, 2019) DER did not have a significant impact on the Market Value Added.

Starting from previous research, researchers were interested in adding ownership certificates to ISO 26000 certificates that could be a guide to the implementation of organizational social responsibility for companies. ISO26000 is represented by seven main issues including corporate governance, human rights, labour activities, the environment, fair operating activities, consumer issues and contributions to the community and society (Rachman et al., 2011: 4). 
The object of the research used in this study is the company that is the winner or who gets an award in the 2016 CSR and TOP CSR 2017 Appreciation. One focus of the assessment is related to CSR alignment with the company's strategy and competitiveness. It is this competitiveness that encourages companies to be responsible for the environment and society so that a good corporate image is formed in the community.

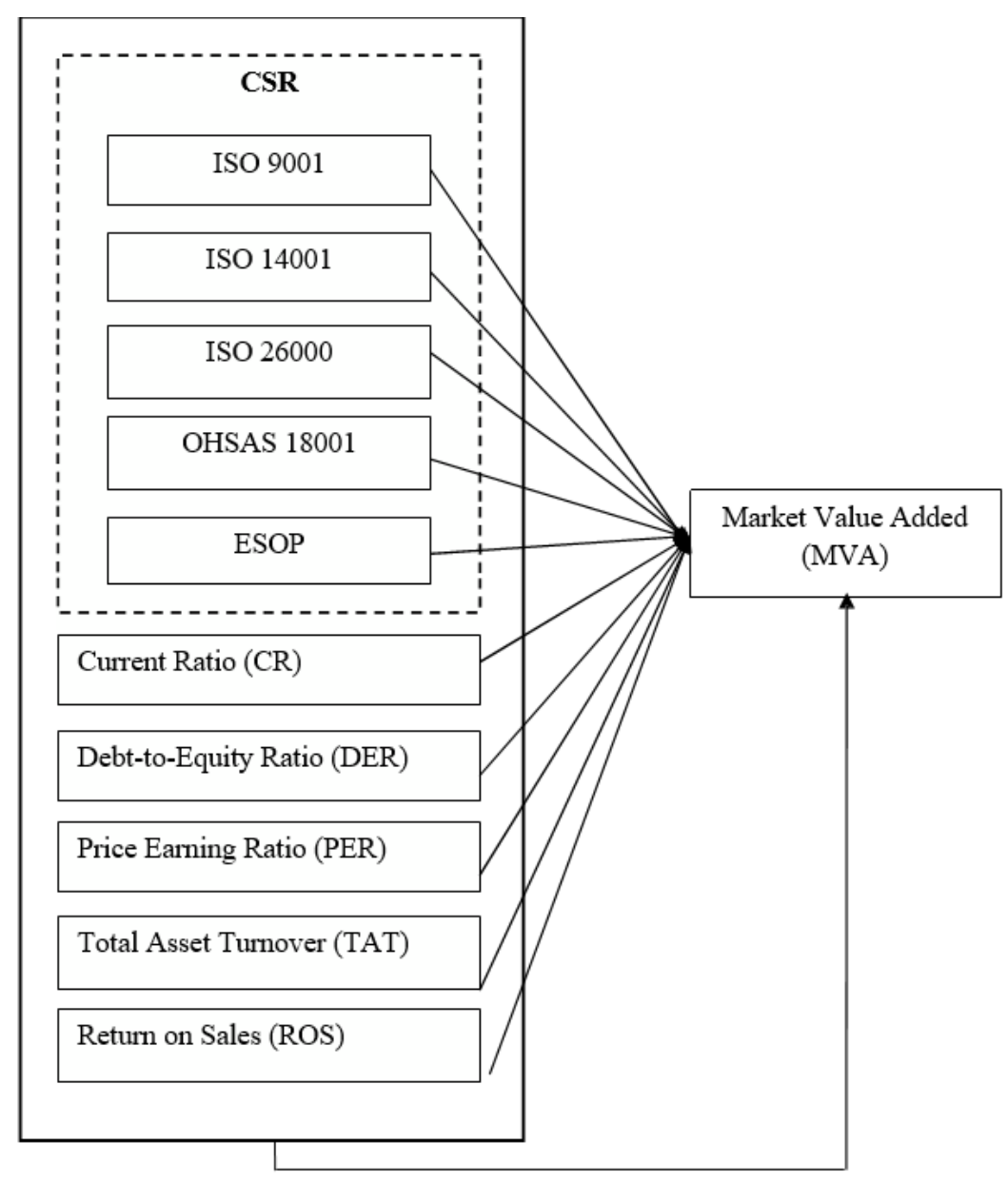

Figure 1. Research Framework

\section{METHODS}

This research is a quantitative descriptive and limits the problems that exist in the formulation of the problem. This study will only focus on companies that get CSR 2016 and TOP CSR 2017 Appreciation awards. The 2016 CSR Appreciation is a mark for the company's acceptance of its social activities, and this award was followed by 22 companies. The 2017 TOP CSR award was chosen as the object of research because one of the focuses of Top CSR 2017 assessment is the fulfilment of ISO 26000 provisions related to CSR alignment with the company's strategy and competitiveness. The event was attended by 117 companies from various industrial sectors. The method used in selecting the sample object of this research is purposive sampling, namely the method of selecting samples with various specific criteria. The criteria used in this study are as follows: (1) companies included in the list of 2017 CSR Appreciation and TOP CSR 2017 Award winners that are listed on the IDX; (2) companies that have complete financial report data in 2015 and 2016. 
Based on the criteria above the total sample used in the study were 33 companies. Data is obtained by downloading data that will be used by accessing from the official website of the award-winning company and the official website of the Indonesia Stock Exchange (www.idx.co.id)

\section{RESULTS AND DISCUSSION}

Table 1.

t-test

\begin{tabular}{|c|c|c|c|c|c|c|}
\hline & Model & $\begin{array}{r}\text { Unstan } \\
\text { Coeff }\end{array}$ & $\begin{array}{l}\text { ardized } \\
\text { ients }\end{array}$ & $\begin{array}{l}\text { Standardized } \\
\text { Coefficients }\end{array}$ & $\mathrm{T}$ & Sig. \\
\hline & & B & Std. Error & Beta & & \\
\hline 1 & (Constant) & 6,299 & 1,423 & & 4,428 &, 000 \\
\hline & ISO9001 & $-1,072$ & 1,349 &,- 148 &,- 794 & , 436 \\
\hline & ISO14001 & 1,437 & 2,715 & 211 &, 529 & ,602 \\
\hline & ISO26000 & $-2,069$ & 2,031 &,- 249 & $-1,019$ & ,319 \\
\hline & OHSAS18001 & 2,450 & 2,569 & ,359 & ,954 & ,351 \\
\hline & ESOP & 2,967 & 1,264 & ,401 & 2,348 & ,028 \\
\hline & CR &,- 008 & 005 &,- 315 & $-1,478$ & ,154 \\
\hline & DER &,- 001 & ,006 &,- 033 &,- 165 & 871 \\
\hline & PER &, 002 & ,010 &, 031 & , 168 & ,869 \\
\hline & TAT &,- 071 & 059 &,- 261 & $-1,204$ & ,242 \\
\hline & ROS &, 098 & 094 & ,226 & 1,038 & ,310 \\
\hline
\end{tabular}

\section{Dependent Variable: MVA}

The results of testing the hypothesis note that Corporate Social Responsibility (CSR) through IS0 9001 does not affect Market Value Adapt (MVA). The negative t value indicates that ISO9001 has an opposite relationship to Market Value Added (MVA). The increase or decrease in ISO9001 will not affect Market Value Added (MVA). Companies that get an ISO 9001 certificate are companies which have guidelines for the quality of their companies. ISO 9001 is the most comprehensive standard and is used to guarantee the quality so that if the company does not comply with these guidelines it will hurt the company's image.

Corporate Social Responsibility (CSR) through IS0 14001 does not affect Market Value Adapt (MVA). Besides, a positive t value indicates that ISO14001 has a relationship with Market Value Added (MVA), although it is not significant. The increase or decrease in ISO9001 will not affect Market Value Added (MVA). The results of this study indicate that companies with ISO 14001 certificates have guidelines for their environment that must be followed according to the rules. These rules must be following environmental quality standards because environmental quality can describe the company's performance. In its development, the company has aspects that must be adhered to in carrying out company activities. If the rules for this environment are not appropriate, it will harm the company, because the company is considered not to run the rules effectively. This causes if it is not following the guidelines, the measure of non-financial performance will be judged to be poor so it will decline the company's image. 
Corporate Social Responsibility (CSR) through IS0 26000 does not affect Market Value Adapt (MVA). A negative t value indicates that ISO26000 has an opposite relationship to Market Value Added (MVA). This shows that companies that implement ISO 26000 have not worked effectively so that they have no influence. The ISO guide to social responsibility emphasizes the importance of public reporting for the performance of social responsibility to stakeholders (GRI-ISO, 2010).

Corporate Social Responsibility (CSR) through OHSAS 18001 has no significant effect on Market Value Adequacy (MVA) in the direction of positive influence. This case happens because not all companies have implemented OHSAS 18001 in their work environment. OHSAS 18001 is intended to assist organizations in controlling occupational safety and health risks within the company. The implementation of this occupational safety \& health management system cannot replicate or be imitated, because each company has its own needs. This shows that companies that implement OHSAS 18001 well and efficiently have not been able to make high changes to the company performance of the winners of Appreciation and Top CSR which impact the company's image.

The results of hypothesis testing indicate that Corporate Social Responsibility (CSR) through ESOP has a significant effect on Market Value Adapt (MVA). This shows that the application of ESOP in the company gives positive things to employee performance. Employees will be motivated so that it will have a good impact on the company. The purpose of this ESOP is to give rewards to all employees for their contribution to the improvement of the company performance (Bapepam, 2002). Increasing company performance from this measure of nonfinancial performance makes the company's image better. The application of ESOP is expected to be one way to attract the attention of employees, where all employees get the opportunity and have the right to own shares in the company where they work(Hartono \& Wibowo, 2017). So that the expected results of employees will be motivated to advance the company. Employees can maximize their performance, in other words, the application of ESOP can improve the company's financial performance which has an impact on the company's image well.

The results of testing the hypothesis note that Current Ratio (CR) does not affect the Market Value Adapt (MVA), with a negative $t$ value indicating that $\mathrm{CR}$ has an opposite relationship to Market Value Added (MVA). There is a negative relationship because of the company high current liabilities that affect the company's CR being too low. This means that the company's ability to meet its short-term obligations is less efficient because the current ratio which is the ratio that describes a company in paying its obligations has a time limit. Besides, the trend analysis of this ratio needs to be done carefully because this ratio can change rapidly and can be easily influenced by management.

Debt to Equity Ratio (DER) does not affect Market Value Adapt (MVA). Based on the ttest there is a negative and no significant relationship to the dependent variable. Thus the increase or decrease in DER will not affect Market Value Added (MVA). Besides, the negative $t$ value indicates that DER has an opposite relationship to Market Value Added (MVA). The negative relationship causes the DER value to be relatively low, this case indicates that the company is lacking to guarantee funds from the back pay, so the company can be said that it is not solvable. Besides, in this study, there are various types of companies engaged in various fields such as industry, minings, and services. These service companies include banks, insurances and investment companies which have a high DER value because the funds managed are third-party funds risking the company performance. 
Price Earnings Ratio (PER) does not affect Market Value Adapt (MVA). This result shows that PER gives risk to the investors even though the risk is a small number in this study. This ratio also does not affect the profit growth expected by the investors. For investors, the higher the

Price Earnings Ratio, more expected profit growth will also increase (Fahmi, 2014: 83). Vice versa, the lower the Price Earnings Ratio, the profit growth will decrease or has a low growth. PER information indicates the amount of rupiah that investors must pay to get one rupiah in company earnings. This ratio can provide understanding for the company management to predict the company's ability to generate profits in the future. But in this study, the priceearnings ratio has not shown its influence on the size of the company's performance in the future which will have an impact on the company's reputation/image.

The results of testing the hypothesis note that Total Asset Turnover (TAT) does not affect the Market Value Adapt (MVA). Based on the t-test there is a negative and no significant relationship to the dependent variable. The increase or decrease in TAT will not affect Market Value Added (MVA). Besides, the negative $t$ value indicates that TAT has an opposite relationship to Market Value Added (MVA). The results of the study show that the overall assets of the company do not occur effectively so that the results of the business decline. This ratio is part of the activity ratio that describes the extent to which a company uses resources to support company activities (Fahmi, 2014:77). However, this ineffective turnover shows that the low level of utilization of company resources is also a factor that affects the decrease in the ratio of Total Asset Turnover. The lower the asset turnover value, the company is considered less efficient in allocating its assets. So that a low total asset turnover does not affect the performance of a company in improving the company's reputation.

Return on Sales (ROS) does not affect Market Value Adapt (MVA). Thus the increase or decrease in ROS will not affect Market Value Added (MVA). Besides, a positive t value indicates that ROS has a direct relationship to Market Value Added (MVA) but is not significant. The results show that the company's operating efficiency is low. A high return on sales shows that the company has a good financial performance. Conversely, a low return on sales indicates that the company has less performance, this is because the sales contribution to the company's profits is low. If this ratio does not have a large influence on the size of the company's performance, this means that with the low corporate performance it does not improve the company's image to stakeholders. Besides, sales contribution that reflects profit does not improve company performance.

Table 2. f-test

\begin{tabular}{|c|c|c|c|c|c|c|}
\hline & Model & $\begin{array}{l}\text { Sum of } \\
\text { Squares }\end{array}$ & Df & $\begin{array}{l}\text { Mean } \\
\text { Square }\end{array}$ & $\mathrm{F}$ & Sig. \\
\hline 1 & Regression & 179,444 & 10 & 17,944 & 1,949 &, $092^{\mathrm{a}}$ \\
\hline & Residual & 202,529 & 22 & 9,206 & & \\
\hline & Total & 381,973 & 32 & & & \\
\hline
\end{tabular}

Predictors: (Constant), ROS, TAT, PER, ISO9001, ESOP, CR, OHSAS18001, DER, ISO26000, ISO14001

Dependent Variable: MVA 
Based on the $f$ test obtained a significant value of $0.092>0.05$ and an $f$ value of 1.949 . The results of testing the hypothesis note that Corporate Social Responsibility (CSR) and all financial ratios together do not affect Market Value Adapt (MVA). The influence of whether or not a financial ratio can be described by the financial condition of a company at that time. Besides, the company's poor performance will certainly have an impact on the company's responsibility. Corporate responsibility is a measure of non-financial performance that is considered to have a large impact on the company's image in the social environment. As a result from companies that are less aware of the benefits of non-financial performance, causes managers to manipulate performance measures that enable managers to achieve their goals, especially to get bonuses (Krismiaji\&Aryani, 2011: 359). Financial ratios and company performance have a close relationship. For investors, they will see the ratio with the use that best fits the analysis that will be carried out (Fahmi, 2014: 50). These results indicate that the company whose won the CSR and Top CSR Appreciation has a change in CSR value and financial ratios both increase and decrease that does not affect Market Value Added (MVA).

\section{CONCLUSION}

Based on the results of research that has been done, it can be concluded that Corporate Social Responsibility (CSR) through ISO 9001, ISO 14001, ISO 26000, OHSAS 18001 has no significant effect on Market Value Added (MVA), while through ESOP, it has a significant effect. Current Ratio (CR), Debt-to-Equity Ratio (DER), Price Earnings Ratio (PER), Total Asset Turnover (TAT), and Return on Sales (ROS) do not have a significant effect on Market Value Added (MVA) in companies that win CSR Appreciation and TOP CSR. Corporate Social Responsibility (CSR) and all financial ratios together have no significant effect on Market Value Added (MVA).

The focus of this study is only on companies that won CSR and Top CSR Appreciation awards for 2016 and 2017, where various fields that meet the research standards are selected. The population in this study is limited to the award winners so that the sample which is less than optimal chosen by the company's Market Value Added (MVA) disclosure. Further research is recommended: (1) Can add companies that win other CSR awards and the latest winning years or researchers can focus on one of the objects of an industrial, service or mining company. (2) The researcher can add another measure of Corporate Social Responsibility (CSR) that supports the company in improving its corporate image. Measuring instruments can be proof of ownership of certificates such as food safety management systems (ISO 22000), and information security management systems (ISO 27001). Researchers can also add other financial ratios to measure company performance, such as Return on Equity (ROE), Dividend Payout Ratio.

\section{REFERENCES}

Abdurachman, A., \& Gustyana, T. T. (2019). Analisis Pengaruh Corporate Social Responsibility (Csr) Terhadap Economic Value Added (Eva) Dan Market Value Added (Mva). JIM UPB (Jurnal Ilmiah Manajemen Universitas Putera Batam), 7(1), 107. https://doi.org/10.33884/jimupb.v7i1.948

Brigham, \& Houston. (2010). Dasar-Dasar Manajemen Keuangan (edisi 11). Jakarta: Salemba Empat

GS, A. D., \& Rahmansyah, M. R. (2017). Implementation of Economic Value Added and Market Value Added Analysis as Valuation Tools to Invest Feasibility. Sinergi : Jurnal Ilmiah Ilmu Manajemen, 7(2), 6-15. https://doi.org/10.25139/sng.v7i2.360 
Hartono, A., \& Wibowo, A. J. (2017). Pengaruh Employee Stock Ownership Program Terhadap Kinerja Perusahaan Publik Di Bursa Efek Indonesia. Modus, 26(1), 85. https://doi.org/10.24002/modus.v26i1.580

Hsu-Chien, H. C. and L. (2010). Research on the Connections Between Corporate Social Responsibility and Corporation Image in the Risk Society: Take the Mobile Telecommunication Industry as an Example. IJEBM, 8(3), 183-194. Retrieved from

Ioannou, I., \& Serafeim, G. (2010). the Impact of Corporate Social Responsibility. SSRN Electronic Journal, 18(3), 1-45. https://doi.org/10.2139/ssrn.1507874

Krismiaji. \& Aryani, A. (2011). Akuntansi Manajemen. Yogyakarta: UPP STIM YKPN

Kurnia, T., Tandiontong, M., \& Maranatha, U. K. (2015). Pada Perusahaan Manufaktur Yang Tercatat Di Bursa Efek Indonesia di Indonesia Magister Akuntansi Fakultas Ekonomi Universitas Kristen Maranatha Bandung 1. Prociding Simposium Nasional Akuntansi XVIII, 1-18. Retrieved from https://repository.maranatha.edu/22808/1/pengaruh Corporate Social.

Novita, R. S. N. S. (2013). Pengaruh Corporate Social Responsibility (CSR) Pada Market Value Added (MVA) Perusahaan Manufaktur Dan Pertambangan. Jurnal Manajemen Teori Dan Terapan, 6(2). https://doi.org/10.20473/jmtt.v6i2.2664

Putri, T. (2014). Analisis Pengaruh Economic Value Added Dan Faktor Fundamental Perusahaan Lainnya Terhadap Return Saham Dengan Corporate Social Resposibility Sebagai Variabel Pemoderasi (Studi Empiris Pada Perusahaan Yang Terdaftar Dalam Indeks Kompas-100 Di BEI Tahun 201. IV(2), 227-248.

Rachman, Nurdizal M., Efendi, Asep, \& Wicaksana, Emir. (2011). Panduan Lengkap Perencanaan Corporate Social Responsibility. Jakarta; Penebar Swadaya.

Salbiah. \& Asmara, Andika Jaka. (2012). Pengaruh Economic Value Added (EVA) terhadap Market Value Added (MVA) pada Perusahaan yang Melakukan Initial Public Offering (IPO) di Bursa Efek Indonesia. Jurnal Ekonom, 15 (3), 135-147.

Song, T., \& Peng, H. (2015). Study of the Relationship between the Sustainable Growing Social Responsibility and EVA Performance Evaluation System of Chinese Central Enterprises. American Journal of Industrial and Business Management, 05(04), 219-225. https://doi.org/10.4236/ajibm.2015.54024

Zhang, J. (2016). Does Corporate Social Responsibility Affect the Financial Performance of Listed Manufacturing Firms in Germany? Faculty of Behavioural, Management and Social Sciences, 01-70. 